\title{
Economic threshold of smooth pigweed escaped from a herbicide program in roundup ready ${ }^{\circledR}$ soybean
}

Renan R. Zandonáa ${ }^{\oplus}$, Geovana F. Barbieri ${ }^{a *}$, Maicon F. Schmitz ${ }^{a} \oplus$, Adriana A. do Amarante ${ }^{\mathrm{a} \oplus}$, João Gabriel S. Göebel ${ }^{\mathrm{a} \odot}$ Dirceu Agostinetto ${ }^{\mathrm{a}}$

a Federal University of Pelotas, Plant Protection Department, Pelotas, RS, Brazil.

Abstract: Introduction: A. hybridus interference in soybeans varies with population size and may be quantified by mathematical models that allow establishing the threshold levels.

Objective: Determine the interference of A. hybridus escaped from an herbicide program and with multiple resistance to EPSPs and ALS-inhibiting herbicides on soybean yield and its economic threshold (ET).

Methods: Two experiments were conducted in a randomized block design. The treatments consisted of populations of $A$. hybridus ranging from 0 to 41 plants $\mathrm{m}^{-2}(2018 / 19)$ and 0 to 32 plants $\mathrm{m}^{-2}(2019 / 20)$. The yield components and yield plant ${ }^{-1}$ of soybean were evaluated. The rectangular hyperbola model was fitted to the soybean yield loss. ET was calculated according to yield potential, price paid for grains, control cost and weed control efficiency

Results: The increase in populations of $A$. hybridus has decreased in the number of pods and grains ${ }^{-1}$ of soybean in both periods. The parameter $i$ was 4.47 and $8.32 \%$, and the ET ranged from 0.16 to 1.21 plants $\mathrm{m}^{-2}$ in 2018/19 and from 0.09 to 0.65 plants $\mathrm{m}^{-2}$ in 2019/20.

Conclusions: One A. hybridus $\mathrm{m}^{-2}$ may reduce $6.4 \%$ in the grain yield of soybean. ET occurs within the range of 0.09 to 1.21 plants $\mathrm{m}^{-2}$.

Keywords: Glycine max; Amaranthus hybridus; populations; yield loss; profitability

Journal Information: ISSN - 2675-9462

Website: http://awsjournal.org

Journal of the Brazilian Weed Science Society

How to cite: Zandoná RR, Barbieri GF, Amarante AA, Göebel JGS, Agostinetto D. Economic threshold of smooth pigweed escaped from a herbicide program in roundup ready ${ }^{\boxplus}$ soybean. Adv Weed Sci. 2022;40(Spec2):e20210011. https://doi.org /10.51694/AdwWeedSci/2022;40:amarathus002

Approved by:

Editor in Chief: Carlos Eduardo Schaedler

Associate Editor: José Barbosa dos Santos

Conflict of Interest: The authors declare that there is no conflict of interest regarding the publication of this manuscript.

Received: March 9, 2021

Approved: October 27, 2021

* Corresponding author: <geovanafacco@hotmail.com>

\section{(c) (1)}

This is an open-access article distributed under the terms of the Creative Commons Attribution License, which permits unrestricted use distribution, and reproduction in any medium, provided that the original author and source are credited.

Copyright: 2021

\section{Introduction}

The species of the genus Amaranthus are among the main weeds found in soybeanproducing regions in Brazil. They are characterized by rapid growth and initial development, intense production of viable seeds per plant, and uneven germination, resulting in emergence flows throughout the growth of agricultural crops (Horak, Loughin, 2000; Netto et al., 2016). Among the species with a wide distribution in Brazil, Amaranthus hybridus stands out with reports of multiple resistance to herbicide inhibitors of the enzymes 5-enolpyruvyl-shikimate-3-phosphate synthase (EPSPs) and acetolactate synthase (ALS) (Heap, 2020). Thus, the ecophysiological characteristics of this species and the existence of biotypes resistant to the most used herbicides for the management of eudicotyledonous weeds make their control difficult and increase the chances of coexistence and competition with soybean.

Competition with weeds is one of the greatest limitations to crop productivity. The level of competition depends on species, population density, phenological stage, and time of weed coexistence with the crop (Vitorino et al., 2017). There are reports of reductions of up to $82 \%$ in soybean productivity due to competition, influencing the formation of productivity components, such as number of pods, number of grains per pod, and weight of grains (Soltani et al., 2017). As an example of species that promote high yield losses in agricultural crops are species of the genus Amaranthus. In cotton, yield losses due to competition with Amaranthus palmeri vary between 6 and $65 \%$ depending on time of emergence and population density (Berger et al., 2015). Similarly, Amaranthus retroflexus in populations of up to 32 plants $\mathrm{m}^{-2}$ promote reductions of $81 \%$ in the productivity of common beans due to competition (Amini et al., 2014).

The evaluation and quantification of crop yield loss by competition due to weeds can use mathematical models, where equations predict the ecophysiological behavior of the crop in the presence of a certain weed (Fleck et al., 2007; Ulguim et al., 2020). Among the models, the most widely used is the rectangular hyperbola model, as it simulates the effects of interference and demonstrates the unit yield loss in relation to plant populations through mathematical parameters (Cousens, 1985a; Fleck et al., 2007). Also, the rectangular hyperbola model makes it possible to estimate the economic threshold (ET) of weeds in crops.

The ET is a measurement for a certain weed population in which the damage caused to the crop grain yield is greater than the cost of the required control measures 
(Vidal et al., 2010). This tool can help in sustainable use of chemical control. The ET equation considers crop yield losses resulting from competition with weeds, expected final productivity, the price paid for the grains produced, costs, and efficiency of weed control (O'Donovan et al., 2005). In this sense, ET is an integrated weed management strategy, since it values the application of herbicides only when they are required (Nunes et al., 2010), thus contributing to maintain the economic viability of agricultural production and bringing socioeconomic benefits to farmers.

With the growing interest in more sustainable production systems that aim to reduce environmental impacts resulting from the use of pesticides and to reduce the selection pressure on weeds by herbicides, models such as the ET help to rationalize the use of herbicides and to determine the ideal population for adopting weed control measures. Thus, the objective of this study is to determine the interference of Amaranthus hybridus escaped from an herbicide program and with multiple resistance to EPSPs and ALS-inhibiting herbicides on soybean productivity and its economic threshold.

\section{Materials and methods}

Two experiments were conducted at the field of Fazenda Chaparral, located at $31^{\circ} 59^{\prime} 49.10^{\prime \prime} \mathrm{S}$ and $53^{\circ} 3^{\prime} 29.46^{\prime \prime} \mathrm{W}$, in the municipality of Herval, Rio Grande do Sul, Brazil, during the 2018/19 and 2019/20 farming seasons. The soil in the area is classified as deep eutrophic Red Yellow Argisol, with an undulating relief.

The experiments were conducted in a no-tillage system in an area with ryegrass (Lolium multiflorum) previously burndown with the herbicides clethodim (120 g a.i. ha $\left.^{-1}\right)$, 2,4-D (1,005 g a.e. ha-1 $)$, and $0.5 \% \mathrm{v} / \mathrm{v}$ of Assist ${ }^{\circledast}$ adjuvant. On the day of soybean sowing, paraquat (300 g a.i. ha ${ }^{-1}$ ) was applied to control the remaining weeds and emerged weeds after the burndown and sulfentrazone + diuron $\left(245+490 \mathrm{~g}\right.$ a.i. ha $\left.{ }^{-1}\right)$ were applied as pre-emergent herbicides. The herbicide applications were carried out with a self-propelled sprayer equipped with $27 \mathrm{~m}$ bars and Teejet 110.02 flat jet tips spaced $0.5 \mathrm{~m}$ apart. The spray volume was calibrated to $120 \mathrm{~L} \mathrm{ha}^{-1}$.

The experimental design was randomized blocks (RBD), with two replications. The treatments were different populations of $A$. hybridus with multiple resistance to EPSPs and ALS-inhibiting herbicides. In experiment 1 (2018/19), the populations of $A$. hybridus were $0,0.3,0.6,1,2,5,7,9$, 18 , 34, and 41 plants $\mathrm{m}^{-2}$; in experiment $2(2019 / 20)$, the populations were $0,0.5,1,2,4,8,16$, and 32 plants $\mathrm{m}^{-2}$. In both experiments, the experimental units with a useful area of $11.45 \mathrm{~m}^{2}$ were selected randomly in commercial Roundup Ready ${ }^{\circledR}$ soybean field. To obtain populations of $A$. hybridus escaped the herbicide, the emergence and natural establishment of this species occurred concomitantly with the soybean crop and the control with the herbicide fomesafen (250 g a.i. ha $\left.{ }^{-1}\right) 20$ days after crop emergence.
The plants escaped the herbicide were monitored, and the population was determined at crop pre-harvest.

The soybean cultivar was BRASMAX ZEUS IPRO ${ }^{\circledR}$, with a population of 240,000 plants $\mathrm{ha}^{-1}$, in rows spaced at $0.45 \mathrm{~m}$. The soil fertilization was carried out at a variable rate following the maps of precision agriculture and the recommendations of the Manual of Fertilization and Liming for the State of Rio Grande do Sul and Santa Catarina to obtain an expected productivity of $3.9 \mathrm{Mg} \mathrm{ha}^{-1}$ (Comissão de Química e Fertilidade do Solo, 2016). The weed control which was not the objective of this study occurred through the application of glyphosate (356 g a.e. ha- ${ }^{-1}$. The management of pests and diseases followed the technical recommendations for soybean.

To verify the interference of populations of A. hybridus, the following components of productivity were evaluated at the time of harvest: number of pods per plant (NPP), number of grains per plant (NGP), total productivity (PROD), and weight of 1,000 grains (WTG) of soybean. To determine NPP and NGP, the plants were harvested in one meter of row and then counted. The WTG was determined by counting eight repetitions of 100 grains per sample and later weighing them on a precision analytical balance. The PROD was obtained by manually harvesting plants in an area of 3.6 and $4.05 \mathrm{~m}^{2}$ in the first and second experiments, respectively. The samples were trailed, cleaned and weighed, and moisture was been determined. Subsequently, the weight was corrected to $13 \%$ moisture and the grain yield was estimated per hectare $\left(\mathrm{kg} \mathrm{ha}^{-1}\right)$. These data were converted into percentage in relation to the controls without the presence of A. hybridus in order to define the loss of each variable by competition, according to the equation:

$$
\mathrm{R}=\left[\frac{(\mathrm{Ta}-\mathrm{Tb})}{\mathrm{Ta}}\right] \cdot 100
$$

where: $\mathrm{R}$ = percentage reduction of each response variable compared to the control; $\mathrm{Ta}=$ treatment value without the presence of A. hybridus (control); and $\mathrm{Tb}=$ observed treatment value.

The data were subjected to analysis of variance by $F$ test $(p<0.05)$, and when significant the linear regression model was fitted for productivity components, as follows:

$$
\mathrm{y}=a+b x
$$

where: $\mathrm{y}=$ response variable; $a$ and $b=$ parameters of linear regression, where $a$ is the intercept and $b$ is the slope.

The relations between the percentage losses of soybean yield as a function of plant population were calculated using the nonlinear regression model derived from the rectangular hyperbola, as proposed by Cousens (1985b):

$$
\mathrm{PR}=\frac{(i \cdot \mathrm{x})}{\left(1+\left(\frac{i}{\mathrm{x}}\right) \cdot \mathrm{x}\right)}
$$

where: $\mathrm{PR}=$ yield loss (\%); $\mathrm{x}=$ plant population of $A$. hybridus; $i=$ percentage of yield loss per weed unit when 
the population approaches zero; and $a=$ percentage of yield loss when the weed population tends to infinity. The model fitting was performed using the multivariate analysis procedure Proc Nlin in the SAS software. For this procedure, the Gauss-Newton method was used, and the graphs were plotted using the software SigmaPlot 12.3.

To calculate ET, the estimates of parameter $i$ were used, obtained from the equation proposed by Cousens (1985b) and the equation adapted from Lindquist and Kropff (1996), as follows:

$$
\mathrm{ET}=\frac{(\mathrm{CC})}{\left(\mathrm{R} \cdot \mathrm{P} \cdot\left(\frac{\mathrm{i}}{100}\right) \cdot\left(\frac{\mathrm{E}}{100}\right)\right)}
$$

where: $\mathrm{ET}=$ level of economic damage (plants $\mathrm{m}^{-2}$ ); Cc = control cost (herbicide and application costs, in dollars $\left.\mathrm{ha}^{-1}\right) ; \mathrm{R}=$ productivity of soybeans $\left(\mathrm{kg} \mathrm{ha}^{-1}\right) ; \mathrm{P}=$ soybean price (dollars $\mathrm{kg}^{-1}$ of grains); $\mathrm{i}=$ percentage of soybean yield loss per weed unit when its density approaches zero, obtained by equation 1 ; and $\mathrm{E}=$ level of herbicide efficiency (\%).

To calculate ET, three values were estimated for R, P, Cc, and $\mathrm{E}$. The crop yield range was estimated at 2,400, 4,200, and $5,400 \mathrm{~kg} \mathrm{ha}^{-1}$, representing low, medium, and high technological level scenarios, respectively. For the price of soybeans, the values of US $\$ 0.17,0.25$, and $0.34 \mathrm{~kg}^{-1}$ were considered representing the minimum, average, and maximum prices of $\mathrm{kg}$ of soybeans, respectively, in the last five years according to the average of Rio Grande do Sul (Companhia Nacional de Abastecimento, 2020). The control cost range was estimated as \$7.01, 12.23, and $29.32 \mathrm{ha}^{-1}$, based on three management scenarios of $A$. hybridus, respectively: scenario 1 (A. hybridus susceptible to EPSPs inhibiting herbicides), scenario 2 (A. hybridus resistant to EPSPs inhibiting herbicides), and scenario 3 (A. hybridus resistant to EPSPs and ALS inhibiting herbicides). The herbicide's efficiency level was established in the order of 80,90 , and $100 \%$ of control, where $80 \%$ is the minimum control considered effective in the weed. In ET simulations, average values were used for each parameter that was not the object of calculation ( $\mathrm{R}=4,200 \mathrm{~kg} \mathrm{ha}^{-1}$; $\mathrm{P}=\mathrm{US} \$ 0.25 \mathrm{~kg}^{-1}$; $\mathrm{E}=90 \%$ ), except for control cost, which value was that of scenario 3 (US\$29.32 ha-1).

\section{Results and discussion}

The result of the analysis of variance indicates significance for all variables analyzed related to yield components in both experiments, except for WTG. The linear polynomial regression model was fitted data obtained for the yield components variables with a statistical significance (Figures 1, 2). Regarding the variable yield loss of grains plant ${ }^{-1}$, there was significance in the two years of test, and the rectangular hyperbola model was fitted this variable (Figure 3 ). To analyze this variable in $2019 / 20$, it was necessary to set the value of the parameter $a$ of the rectangular hyperbola at $100 \%$ (Figure $3 \mathrm{~b}$ ), as the model

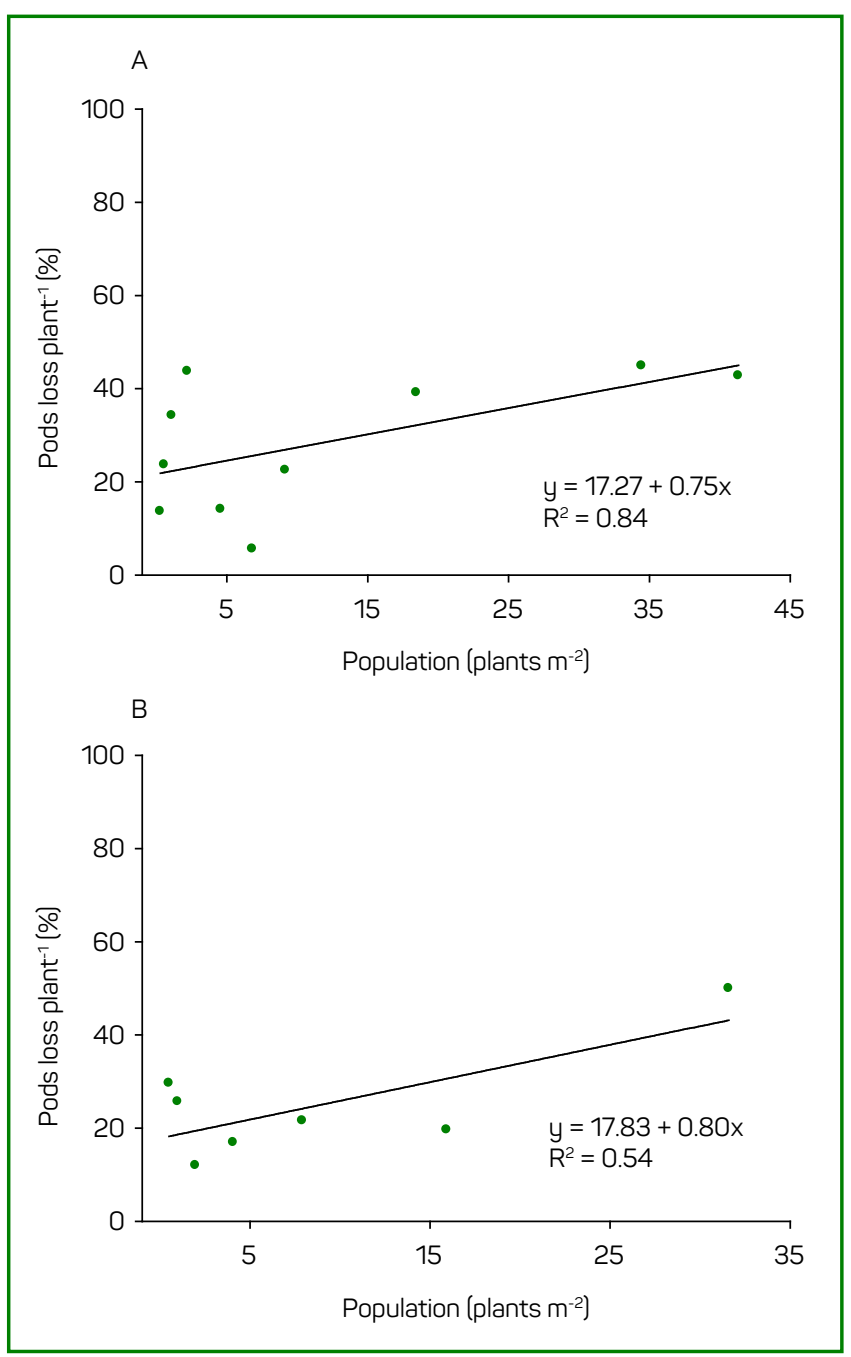

Figure 1 - Pods loss plant ${ }^{-1}$ of soybean (\%) as a function of Amaranthus hybridus populations with multiple resistance to EPSPs and ALS-inhibiting herbicides in the experiments conducted in 2018/19 (a) and 2019/20 (b)

was unable to estimate the total yield loss that year. This usually occurs when populations are not sufficient to cause such damage, as reported for populations of Echinochloa spp. in a study that assessed the Oryza sativa L. yield loss (Ulguim et al., 2020).

Regarding productivity components, the effects of the competition of A. hybridus populations on the loss of pods plant ${ }^{-1}$ of soybean were similar in both test years. The linear coefficient (b) was 0.75 for 2018/19 (Figure 1a) and 0.80 for $2019 / 20$ (Figure 1b). As for the loss of soybeans grains plant ${ }^{-1}$, the experiment conducted in 2018/19 presented a linear coefficient $(b)$ of 0.57 (Figure $2 a)$ and the experiment conducted in 2019/20 had a linear coefficient of 1.07 (Figure 2b), showing a greater grain loss in the second year of the experiment. In general, in both growing seasons, the increase in the population of $A$. hybridus promoted a decrease in the number of pods and grains plant ${ }^{-1}$ of soybean. In the 2018/19 and 
2019/20 crops, losses of pods plant ${ }^{-1}$ reached 45 and $50 \%$ (Figure $1 \mathrm{a}, \mathrm{b}$ ), while losses of beans plant ${ }^{-1}$ reached 49 and $56 \%$ (Figure 2a, b), respectively.

Similarly to the results found in this study, the interference of Conyza bonariensis negatively affected the soybean yield components. There was a reduction in the number of pods plant ${ }^{-1}$, number of pods plant ${ }^{-1}$, and weight of a thousand grains plant ${ }^{-1}$ with the increase in populations (Trezzi et al., 2015). Likewise, these same variables responded in an inversely proportional way to the increase in populations of Ipomoea grandifolia and Ipomoea purpurea. Plant population was the main interfering factor in soybean yield components (Pagnoncelli et al., 2017). In other crops such as chickpeas (Cicer arietinum L.), the same behavior also occurred. The increase in the population from 5 to 40 plants $\mathrm{m}^{2}$ of Euphorbia dracunculoides promoted reductions of 50 and $80 \%$ in the number of pods and grains plant $^{-1}$, respectively (Tanveer et al., 2015).

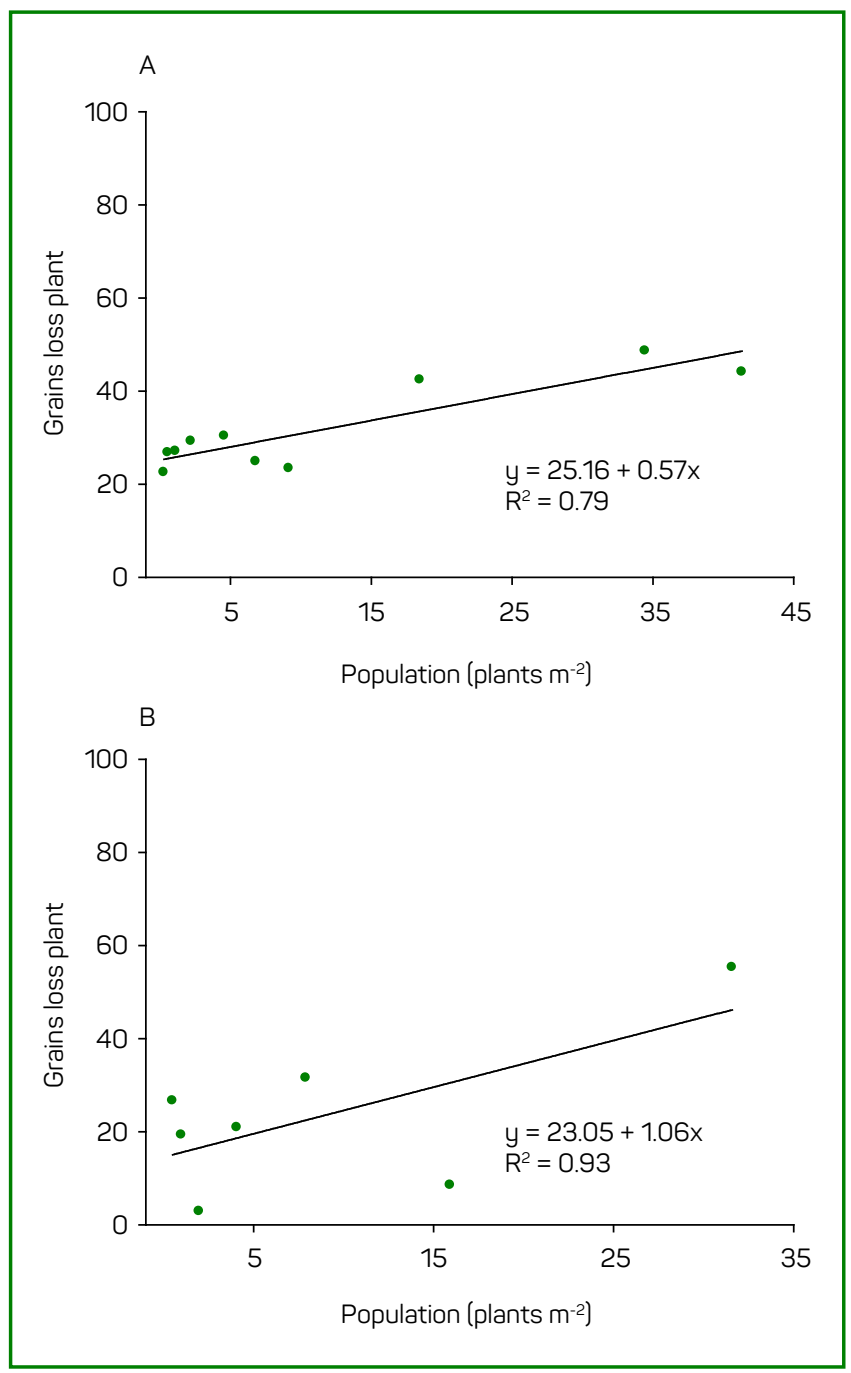

Figure 2 - Grains loss plant ${ }^{-1}$ of soybean (\%) as a function of Amaranthus hybridus populations with multiple resistance to EPSPs and ALS-inhibiting herbicides in the experiments conducted in 2018/19 (a) and 2019/20 (b)
Based on the regression analysis using the rectangular hyperbola model, the estimated parameter $i$ was 4.47 and $8.32 \%$ for the experiment conducted in 2018/19 and $2019 / 20$, respectively. These results show that each plant of A. hybridus reduced the productivity of soybeans by $4.47 \%$ and $8.32 \%$ in the first and second year, respectively, which represents a greater unit yield loss per plant of $A$. hybridus in the second crop season (Figure 3a, b).

Comparisons between the interference of different weed species in crops can be performed using the estimated parameter $i$ (Rizzardi et al., 2003). Thus, in relation to other species of Amaranthus, the loss of soybean yield when the density of Amaranthus palmeri is close to zero was $20.28 \%$, with a maximum yield loss around $49 \%$ (Basinger et al., 2019). Also, in relation to the yield loss of soybeans, the values of the parameter $i$ varied from 6.30 to $30.80 \%$ and from 7.80 to $66.40 \%$. The maximum yield loss was from 3.70 to $44.90 \%$ and from 21.80 to $62.80 \%$ for Amaranthus
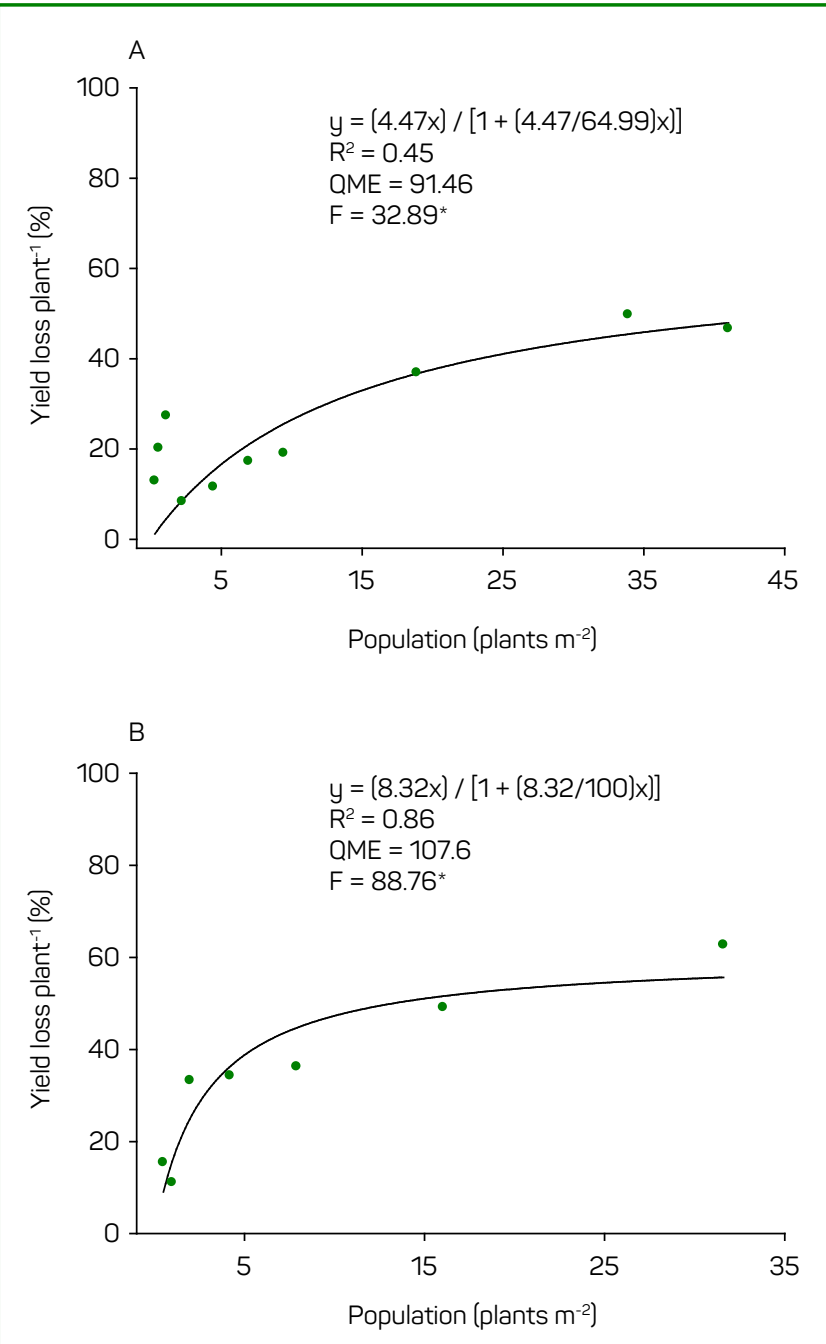

Figure 3 - Yield loss plant ${ }^{-1}$ of soybean (\%) as a function of Amaranthus hybridus populations with multiple resistance to EPSPs and ALS-inhibiting herbicides in the experiments conducted in 2018/19 (a) and 2019/20 (b) 
retroflexus and Amaranthus rudis, respectively, depending on the location and the experiment year (Bensch et al., 2003). In maize, each plant of $A$. retroflexus promoted a reduction of 7.45 to $10.82 \%$ in grain productivity and maximum yield losses of 35.50 to $52.40 \%$ according to the crop plant density (Vazin, 2012). These results show the high interference capacity of Amaranthus species in crop productivity, evidencing an adequate management of these species in agricultural areas.

The unitary soybean yield losses found for A. hybridus in the present work (4.47 and 8.32\%) are higher when compared to Sida rhombifolia ( $i=0.24$ to $2.20 \%$ ), Cyperus rotundus ( $i=0.83$ to $1.0 \%$ ), and Urochloa plantaginea ( $i$ $=1.0$ to $2.5 \%)$, that are also important weeds in soybean (Das et al., 2014; Fleck et al., 2002; Galon et al., 2019). However, Ipomoea purpurea and Ipomoea grandifolia are more competitive with soybean: the parameter $i$ was $26 \%$ and the maximum yield loss was $80 \%$ in a population of 20 plants $\mathrm{m}^{-2}$ (Pagnoncelli et al., 2017). Likewise, for the soybean cultivar BRASMAX TURBO in the presence of C. bonariensis resistant to the herbicide glyphosate, the parameter $i$ was $25.90 \%$ and the maximum yield losses were 95\% (Agostinetto et al., 2017).

The ET values calculated for A. hybridus depend on the productive potential of the soybean crop, price paid for the grains produced, control cost, and efficiency in weed control (Figure 4). Thus, the decisions for the economic control of $A$. hybridus changed according to the levels of these parameters. In addition, the ET varied between test years, with values from 0.16 to 1.21 plants $\mathrm{m}^{-2}$ in $2018 / 19$ and from 0.09 to 0.65 plants $\mathrm{m}^{-2}$ in 2019/20. In the second year (2019/20), due to a greater soybean yield loss per unit of $A$. hybridus (Figure $3 \mathrm{~b})$, the ET for this weed was obtained in smaller populations compared to the first year in all simulations (Figure 4).
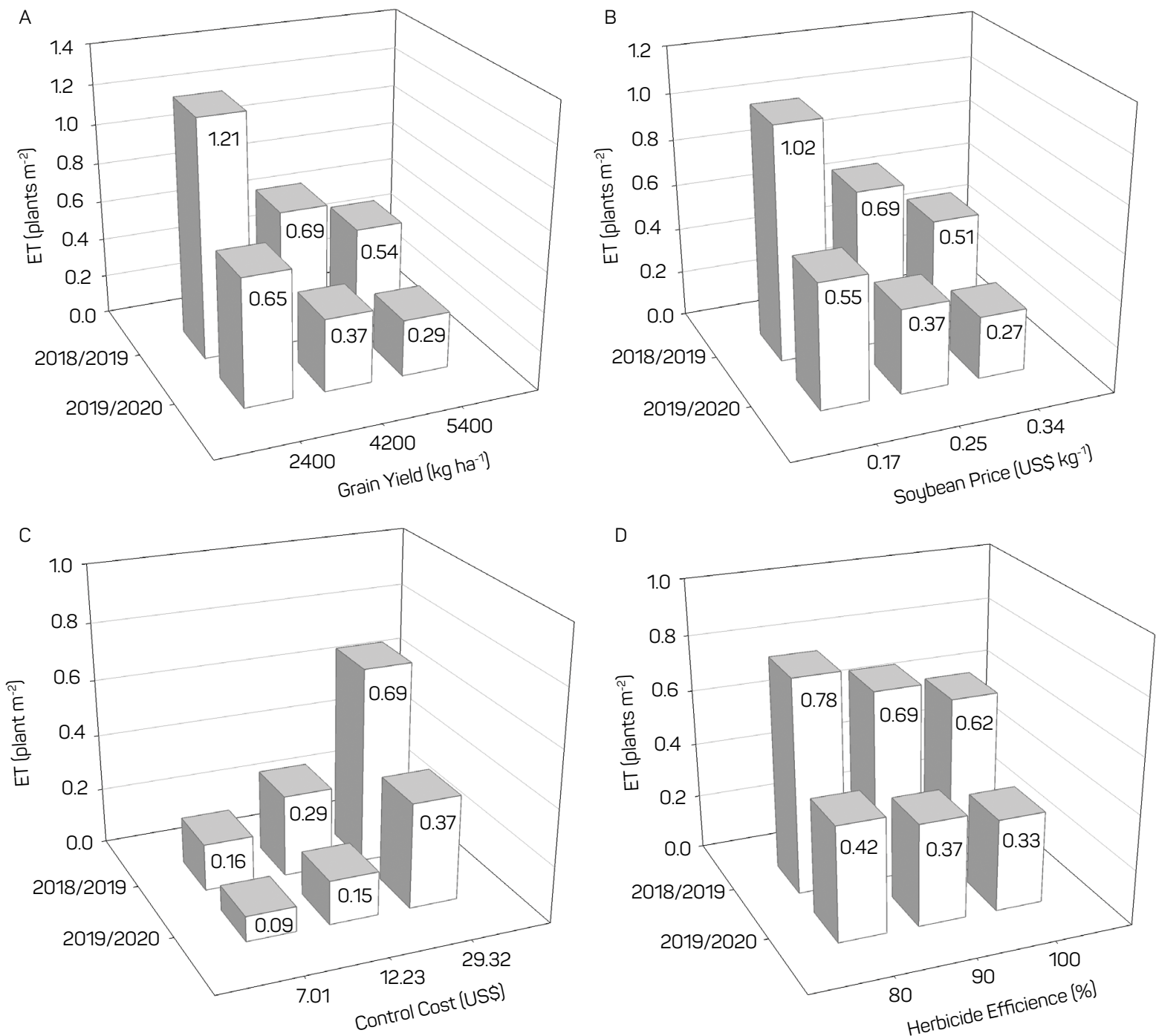

Figure 4 - Economic threshold (ET) of Amaranthus hybridus with multiple resistance in soybean as a function of grain yield (a), soybean price (b), control cost (c), and herbicide efficiency (d) in experiment 1 (2018/19) and experiment 2 (2019/20) 
In simulations of increased soybean yield potential from 2,400 to $5,400 \mathrm{~kg} \mathrm{ha}^{-1}$ and the price of grains produced from 0.17 to $0.34 \mathrm{US} \$ \mathrm{~kg}^{-1}$, there was a reduction of around 55 and $50 \%$, respectively, in the ET values in both years (Figure $4 a, b$ ). This result shows that in areas where management is based on higher soybean yield expectations, the ET is achieved in smaller populations of A. hybridus, compensating for the adoption of control measures. This is also observed for the price paid for produced grains, which fluctuates according to the supply and demand of this commodity: as prices increase, the control of $A$. hybridus in smaller populations becomes economically viable. Corroborating these results, in scenarios of increased expectations of soybean productivity and the price paid for grains there were lower values of ET for glyphosateresistant C. bonariensis (Agostinetto et al., 2017).

Weed resistance to herbicides results in an increase in the control cost due to the need to use alternative herbicides, increasing the production costs of agricultural activity (Pannell et al., 2016). In this sense, in a scenario of multiple resistance of $A$. hybridus to EPSPs and ALS-inhibiting herbicides, the estimated control costs were US $\$ 22.31$ higher than the control cost of susceptible A. hybridus. The increase in the control cost from $\$ 7.01$ (A. hybridus susceptible) to $\$ 29.32$ (A. hybridus with multiple resistance) resulted in an increase in ET from 0.16 to 0.69 plants $\mathrm{m}^{-2}$ and 0.09 for 0.37 plants $\mathrm{m}^{-2}$ in 2018/19 and 2019/20, respectively. Thus, the use of alternative herbicides to control A. hybridus with multiple resistance, such as protoporphyrinogen oxidase (PROTOX) inhibitors used for the simulation in the present study, increases the control cost and makes it economically viable at higher infestation levels.

Another important factor in determining the ET is control efficiency. When control efficiency is low due to factors related to herbicide, weed, and/or climatic conditions, larger weed populations are necessary to economically justify the adoption of control measures (Aguiar et al., 2018). The increase in the efficiency of the herbicide leads to a decrease in ET values (Figure 4d). There were small variations in the ET calculated for A. hybridus in relation to the increase in efficiency, ranging from 0.62 to 0.78 plants $\mathrm{m}^{-2}$ in 2018/19 and from 0.33 to 0.42 plants $\mathrm{m}^{-2}$ in 2019/20. However, these ET values can be easily reached at different times in the crop development due to the long period of Amaranthus spp. emergence and the ease of seed bank renewal due to the large amount of seeds produced per plant.
Among the simulations carried out in 2018/19 and 2019/20, the maximum ET value found for A. hybridus with multiple resistance to EPSPs and ALS-inhibiting herbicides in soybeans was 1.21 plants $\mathrm{m}^{-2}$. Compared to this result, the maximum ET found for A. retroflexus in corn was 0.13 plants $\mathrm{m}^{-2}$ (Vazin, 2012) and for voluntary corn Roundup Ready in soybeans was 0.48 plants $\mathrm{m}^{-2}$ (Aguiar et al., 2018), showing economic control of populations smaller than those found for A. hybridus (Figure 4). Likewise, higher ET values in relation to those found in this study occur for weeds such as Urochloa plantaginea (Galon et al., 2019), C. bonariensis (Trezzi et al., 2015), Bidens spp. (Rizzardi et al., 2003), and S. rhombifolia (Fleck et al., 2002), with maximum estimated ETL values of 2.16, 4, 33, and 50 plants $\mathrm{m}^{-2}$, respectively.

From a strategic point of view, the knowledge of these parameters helps in decision-making and in the development of management programs for A. hybridus with multiple resistance to herbicides inhibiting the enzymes EPSPs and ALS. As the economic threshold of plants of A. hybridus in soybean is reached in populations smaller than 1.21 plants $\mathrm{m}^{-2}$, control measures must be effectively carried out even in low populations, as they are economically viable and, above all, reduce the possibility of propagating the species and renewing the weed seed bank.

\section{Conclusion}

Only one plant of A. hybridus per $\mathrm{m}^{-2}$ with multiple resistance to the EPSPs and ALS-inhibiting herbicides can reduce on average $6.4 \%$ the soybean grain yield. The threshold level occurs within the range of 0.09 to 1.21 plants per $\mathrm{m}^{-2}$.

\section{Authors' contributions}

All authors contributed equally to the design and writing of the manuscript.

\section{Acknowledgements}

The authors would like to thank the Coordination for the Improvement of Higher Education Personnel (Capes) for Master's and doctorate fellowships. To National Council for Scientific and Technological Development (CNPq) for the research productivity grant from for Dr. Dirceu Agostinetto/Proc. No. 308363/2018-3.

\section{References}

Agostinetto D, Silva DRO, Vargas L. Soybean yield loss and economic thresholds due to glyphosate resistant hairy fleabane interference. Arq Inst Biol. 2017;84:1-8. Available from: https://doi.org/10.1590/1808-1657000022017

Aguiar ACM, Basso CJ, Muraro DS, Pansera E, Silva DRO. Interference and economic threshold level of volunteer corn in soybean. Planta Daninha. 2018;36:1-10. Available from: https://doi.org/10.1590/s0100-83582018360100134

Amini R, Alizadeh $H$, Yousefi A. Interference between red kidneybean (Phoseolus vulgaris L.) cultivars and redroot pigweed (Amoronthus retroflexus L.). Eur J Agron. 2014;60:13-21. Available from: https://doi.org/10.1016/j.eja.2014.07.002 
Basinger NT, Jennings KM, Monks DW, Jordan DL, Everman WJ, Hestir EL et al. Large crabgrass (Digitorio sanguinalis) and Palmer amaranth (Amoronthus polmeri) intraspecific and interspecific interference in soybean. Weed Sci. 2019;67(6):649-56. Available from: https://doi.org/10.1017/wsc.2019.43.

Bensch CN, Horak MJ, Peterson D. Interference of redroot pigweed (Amaranthus retroflexus), Palmer amaranth (A. palmeri), and common waterhemp (A. rudis) in soybean. Weed Sci. 2003;51(1):37-43. Available from: https://doi.org/10.1614/0043-1745(2003)051[0037:IORPAR]2.0.C0;2

Berger ST, Ferrell JA, Rowland DL, Webster TM. Palmer amaranth (Amaranthus palmeril competition for water in cotton. Weed Sci. 2015;63(4):92835. Available from: https://doi.org/10.1614/WS-D-15-00062.1

Comissão de Química e Fertilidade do Solo - CQFS. [Liming and fertilization manual for the states of Rio Grande do Sul and Santa Catarina]. 11th ed. Porto Alegre: Sociedade Brasileira de Ciência do Solo; 2016. Portuguese.

Companhia Nacional de Abastecimento - Conab. [Soybean: comparison of area, grain yield and production: crop 2015/2016 - 2020/2021] Brasília: Companhia Nacional de Abastecimento; 2020[accessed Aug, 2020]. Portuguese. Available from: http://www.conab.gov.br

Cousens R. A simple model relating yield loss to weed density. Ann Appl Biol. 1985a;107(2):239-52. Available from: https://doi. org/10.1111/j.1744-7348.1985.tb01567.x.

Cousens R. An empirical model relating crop yield to weed and crop density and a statistical comparison with other models. J Agric Sci. 1985b;105(3):513-21. Available from: https://doi.org/10.1017/ S0021859600059396

Das TK, Paul AK, Yaduraju NT. Density-effect and economic threshold of purple nutsedge (Cyperus rotundus) in soybean. J Pest Sci. 2014;87:21120. Available from: https://doi.org/10.1007/s10340-013-0536-4

Fleck NG, Lamego FP, Schaedler CE, Ferreira FB. [Soybean cultivar response to competition with a weed mimicking genotype]. Sci Agrar. 2007;8(3):213-18. Portuguese. Available from: https://doi.org/10.5380/ rsa.v8i3.9520

Fleck NG, Rizzardi MA, Agostinetto D. [Threshold level as a criteria for arrowleaf sida control decision in soybeans]. Planta Daninha. 2002;20(3):421-29. Portuguese. Available from: https://doi. org/10.1590/S0100-83582002000300013

Galon L, Oliveira Rossetto ER, Fransceschetti MB, Bagnara MAM, Bianchessi $F$, Menegat $A D$ et al. Interference and economic threshold level of alexander grass in soybean as a function of cultivars and weed populations. Int J Adv Res Technol. 2019;6(7):73-81. Available from: https://doi.org/10.22161/ijaers.6710

Heap, I. The international herbicide-resistant weed database. WeedScience. 2020[accessed Sept 2020]. Available from: www.weedscience.org.

Horak MJ, Loughin TM. Growth analysis of four Amoronthus species. Weed Sci. 2000;48(3):347-55. Available from: https://doi.org/10.1614/ 0043-1745(2000)048[0347:GAOFAS]2.0.C0;2

LindquistJL, KropffMJ.Applications ofanecophysiological model for irrigated rice (Oryzo sotivo): Echinochloo competition. Weed Sci. 1996;44(1):526. Available from: https://doi.org/10.1017/S0043174500093541
Netto AG, Nicolai M, Carvalho SJP, Borgato EA, Christoffoleti PJ. Multiple resistance of Amoronthus polmeri to ALS and EPSPS inhibiting herbicides in the State of Mato Grosso, Brazil. Planta Daninha. 2016;34(3):581-87. Available from: https://doi.org/10.1590/s010083582016340300019

Nunes AL, Trezzi MM, Debastiani C. [Integrated management of weeds in maize culture]. Bragantia. 2010;69(2):299-304. Portuguese. Available from: https://doi.org/10.1590/S0006-87052010000200006

O'Donovan JT, Blackshaw RE, Harker KN, Clayton GW, Maurice DC. Field evaluation of regression equations to estimate crop yield losses due to weeds. Can J Plant Sci. 2005;85(4):955-62. Available from: https://doi.org/10.4141/P05-041

Pagnoncelli FDB, Trezzi MM, Brum B, Vidal RA, Portes ÁF, Scalcon EL et al. Morning glory species interference on the development and yield of soybeans. Bragantia. 2017;76(4):470-79. Available from: https://doi.org/10.1590/1678-4499.2016.338

Pannell DJ, Tillie P, Rodríguez-Cerezo E, Ervin D, Frisvold GB. Herbicide resistance: economic and environmental challenges. AgBioForum. 2016;19(2):136-55.

Rizzardi MA, Fleck NG, Mundstock CM, Bianchi MA. [Soybean grain yield losses due to interference by beggatticks and arrowleaf sida]. Cienc Rural. 2003;33(4):621-7. Portuguese. Available from: https://doi.org/10.1590/S0103-84782003000400005

Soltani N, Dille JA, Burke IC, Everman WJ, VanGessel MJ, Davis VM et al. Perspectives on potential soybean yield losses from weeds in North America. Weed Technol. 2017;31(1):148-54. Available from: https://doi.org/10.1017/wet.2016.2

Tanveer A, Javaid MM, Irfan M, Khaliq A, Yaseen M. Yield losses in chickpea with varying densities of dragon spurge (Euphorbia dracunculoides). Weed Sci. 2015;63(2):522-28. Available from: https://doi.org/10.1614/WS-D-13-00049.1

Trezzi MM, Vidal RA, Patel F, Miotto Jr E, Debastiani F, Balbinot Jr AA et al. Impact of Conyzo bonariensis density and establishment period on soybean grain yield, yield components and economic threshold. Weed Res. 2015;55(1):34-41. Available from: https://doi.org/10.1111/wre.12125

Ulguim AR, Avila Neto R, Carlos FS, Streck NA, Richter GL. Understanding nutrient competition between Echinochloo spp. and Oryzo sativa L. J Plant Prot Res. 2020;60(3):296-310. Available from: https://doi.org/10.24425/jppr.2020.133320

Vazin, F. The effects of pigweed redroot (Amaranthus retoflexus) weed competition and its economic thresholds in corn (Zeo mays). Planta Daninha. 2012;30(3):477-85. Available from: https://doi.org/10.1590/ S0100-83582012000300003

Vidal RA, Kalsing A, Gherekhloo J. [Interference and economic threshold level of Brochioria plantagineo and Ipomoeo nil in common bean culture]. Cienc Rural. 2010;40(8):1675-81. Portuguese. Available from: https://doi.org/10.1590/S0103-84782010000800001

Vitorino HDS, Silva Junior ACD, Gonçalves CG, Martins D. Interference of a weed community in the soybean crop in functions of sowing spacing. Rev Cienc Agron. 2017;48(4):605-13. Available from: https://doi.org/10.5935/1806-6690.20170070 